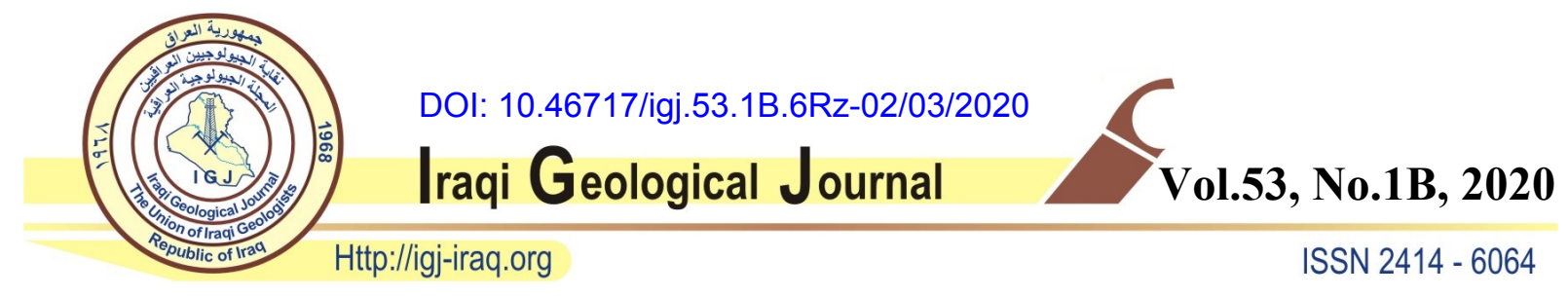

\title{
RESERVOIR MODELING OF MISHRIF FORMATION IN MAJNOON OIL FIELD, SOUTHERN IRAQ \\ ${ }^{1}$ Layla khudhur Abbas ${ }^{*}$ and ${ }^{2}$ Thamar Abdullah Mahdi \\ ${ }^{1,2}$ Department of Geology, College of Science, University of Baghdad, Baghdad, Iraq \\ "E-mail: Laylakhadir@yahoo.com
}

Received: 29 May 2019; accepted: 21 October 2019

\begin{abstract}
The Middle Cenomanian-Early Turonian Mishrif Formation includes important carbonate reservoirs in Iraq and some other surrounding countries due to their high reservoir quality and wide geological extension. The $2 D$ models of this study for facies, effective porosity and water saturation indicate the vertical and lateral heterogeneity of the Mishrif Formation reservoir properties in the Majnoon oil field. Construction of $2 D$ reservoir model of the Mishrif Formation to explain the distribution of facies and petrophysical properties (effective porosity and water saturation) by using RockWorks software. The increase of effective porosity is attributed to the presence of shoal facies. The high water saturation is attributed to the existence of restricted marine facies or shallow open marine facies. Maximum values of hydrocarbon saturation are predicted to occur towards the crestal parts of the field.
\end{abstract}

Keywords: Reservoir modeling; Mishrif Formation; Majnoon oil field

\section{INTRODUCTION}

The Mishrif Formation is the most important carbonate reservoir unit in the south of Iraq and it contains up to $30 \%$ of the total Iraqi oil reserves (Aqrawi et al., 2010). The reservoir units of the Mishrif Formation in southern Iraq occur at locations where the rudistid facies with appropriate porosity and permeability are developed at different structural elevations of Mesopotamian basin's Oilfields (Mahdi and Aqrawi, 2017). The task of the reservoir geologists is to identify such reservoir units. Therefore, it is essential to model reservoir characteristics to understand inter well-scale heterogeneities of facies and petrophysical properties. This study incorporates well logs data combined with facies data to establish the geological model of the Mishrif Formation in Majnoon Oilfield. In this study RockWorks 
(2016) software is used to build static 2D models for facies, porosity and water saturation of the Mishrif Formation in Majnoon Oilfield.

\section{THE STUDY AREA}

The study area is located in Majnoon Oilfield, located in southern Iraq, Basrah and Missan Governorate; $70 \mathrm{~km}$ to the northwest of Basra city, close to Iraqi-Iranian borders (Fig. 1).

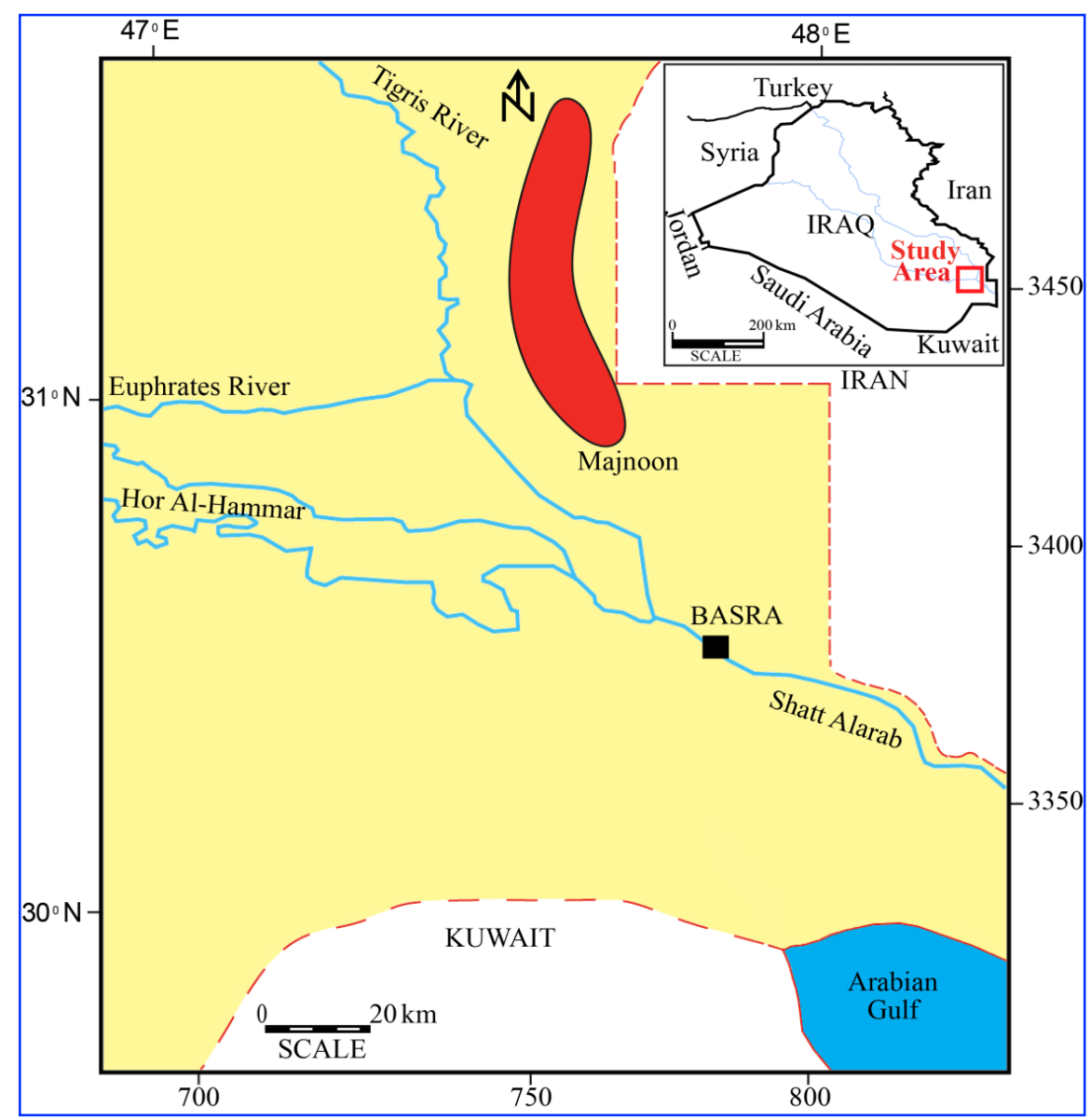

Fig. 1: Location map of the study area (modified from Al-Ameri et al., 2012)

\section{GEOLOGICAL SETTING}

The study area is located in Zubair Subzone, which considered the most prolific petroleum region in Iraq (Jassim and Goff, 2006). This subzone forms the southernmost unit of Mesopotamian Zone and has a uniform structural style by the underlying basement. It incorporates prominent N-S trending structures (Fig. 2), which continue hundreds of kilometers southwards (Jassim and Goff, 2006). Figure (2) shows the limited change in the structural attitude of Majnoon Oilfield during the deposition of the Mishrif Formation as indicated by shifting of structural closure towards north and south directions. 
The type section of Mishrif Formation was described as a heterogeneous succession of organic detrital limestone, with algal beds, rudist, and limestone of coral-reef, capped by limonitic fresh water limestone (van Bellen et al., 1959-2005). This description was given by Rabanit (1952), who first described the formation in the Zubair area of southern Iraq (Buday, 1980). The contact between the Mishrif and Rumaila formations is gradational as is the contact between the Mishrif and Kifil Formations. However, in many oilfields the Mishrif Formation is unconformably overlain by the Khasib Formation where the Kifil Formation is absent in the study area (Aqrawi et al., 1998).

The formation was deposited as rudist shoals and patch of reefs over growing subtle structural highs developing in an otherwise relatively deeper shelf on which open marine sediments of the Rumaila Formation were deposited (Jassim and Goff, 2006) (Fig. 3).

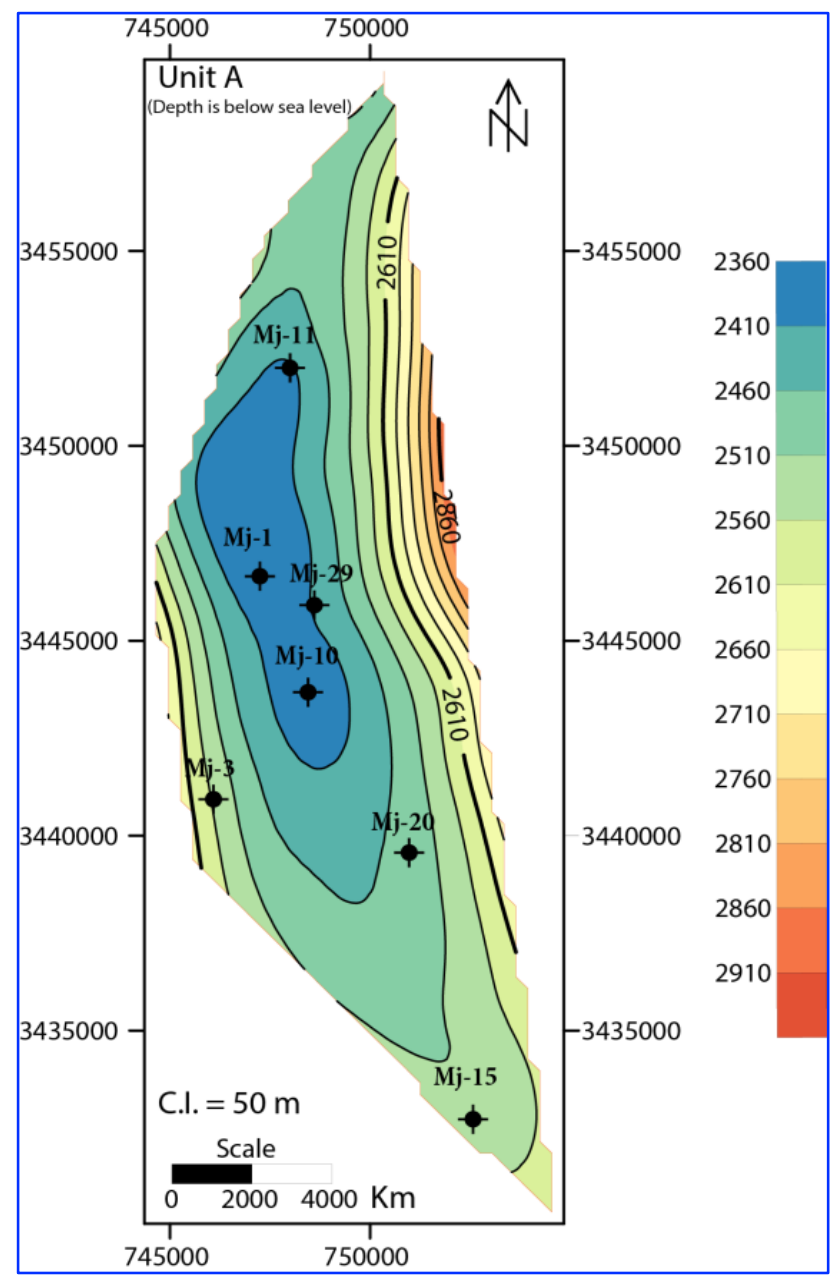

Fig. 2: Structure contour map at the top of Mishrif Formation in Majnoon Oilfield 


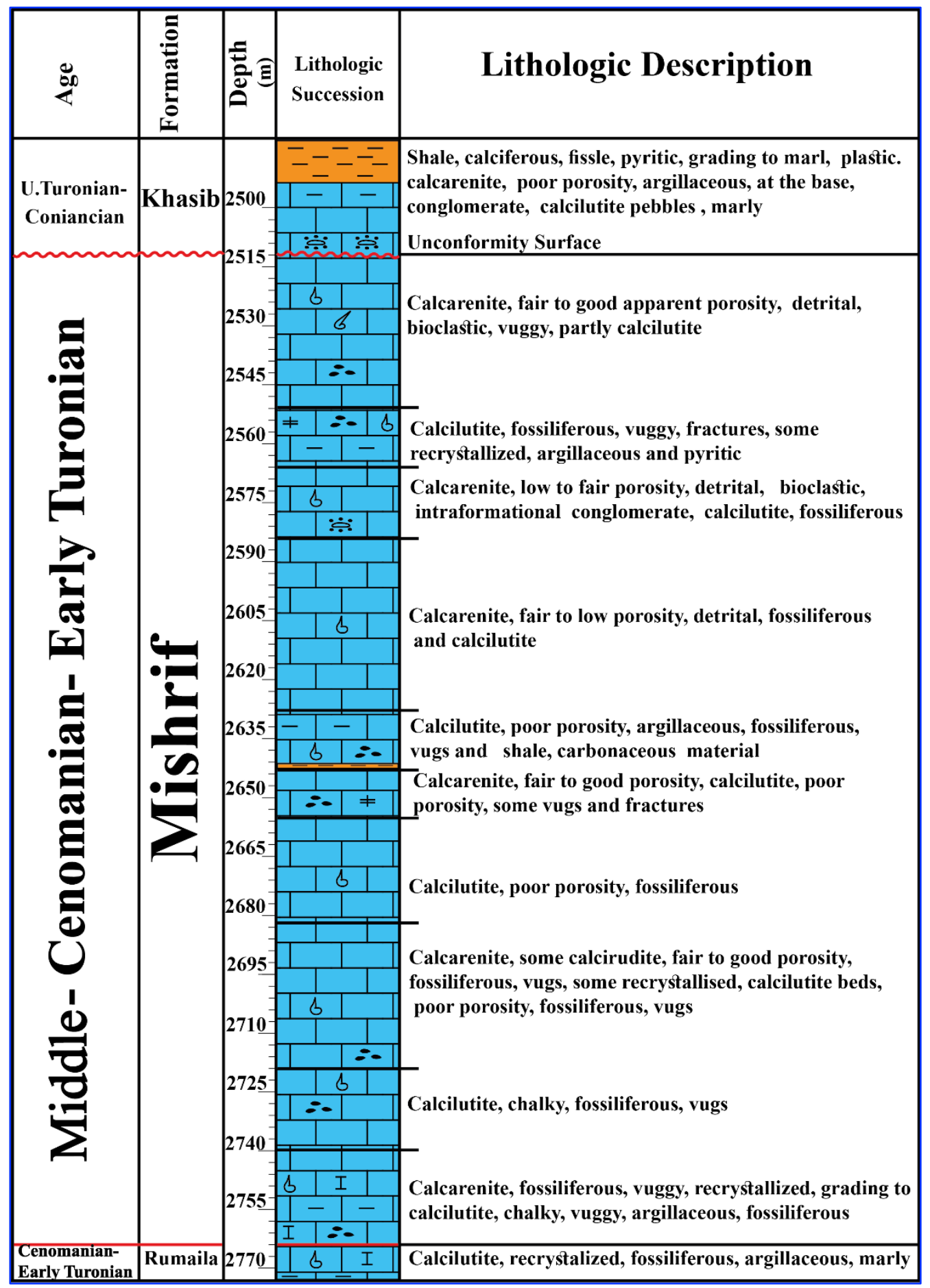

Fig. 3: Stratigraphic succession of Mishrif Formation in well Mj-2 (lithologic description is adapted from Braspetro, 1978)

\section{MATERIALS AND METHODS}

Microfacies analysis of the thin section of cuttings and core samples. Well logs analysis and the calculation of the petrophysical properties by using IP software. Construction 2D reservoir 
models of Mishrif Formation in two directions along the studied wells to explain the facies and petrophysical properties distribution by using RockWorks (2016) software. Where two types of data were imported to RockWorks (2016) for simulation. These are I-data and P-data where I-data includes facies association and P-data includes the petrophysical properties (effective porosity and water saturation) that derived from well logs analysis. The porosity model shows the distribution of effective porosity values calculated from analysis of porosity logs in IP software. Effective porosity values imported from IP to RockWorks (2016) software as a data point. The data point is used to enter measured values which are sampled at single depth points (as opposed to depth intervals) down the boreholes. The following formula was used to calculate effective porosity:

$$
\phi_{e}=\phi_{t} \times\left(1-V_{s h}\right)
$$

Where: $\phi_{\mathrm{e}}=$ effective porosity, $\phi_{\mathrm{t}}=$ total porosity ( $\left.\phi_{\mathrm{N} . \mathrm{D}}\right)$ calculated from the averaged porosity of the neutron and porosity that calculated from the density log, Vsh = volume of shale that calculated from Dresser Atlas (1979) used to determine the volume of shale for older rocks by using the following equation:

$$
V_{s h}=0.33 \times\left[2^{\left(2 \times I_{G R}\right)}-1\right]
$$

Where: Vsh = volume of shale, IGR= gamma ray index.

The water saturation model considers the water saturation values that were calculated by IP software. Water saturation values were imported to RockWorks as a data point (P-Data). The following formula was used to determine water saturation of the uninvaded zone:

$$
S w=\left(\frac{a \times R_{w}}{\phi^{m} \times R_{t}}\right)^{\frac{1}{n}}
$$

Where: $S_{w}=$ water saturation of the uninvaded zone, $R_{w}=$ resistivity of formation water at formation temperature $\left(0.020 @ 120^{\circ} \mathrm{F}\right), R_{t}=$ true formation resistivity (i.e., deep induction or deep laterolog), $\phi=$ porosity, $a=$ tortuosity factor $(\mathrm{a}=1.3), m=$ cementation exponent $(\mathrm{m}=1.62), n=$ saturation exponent $(\mathrm{n}=2.15)$.

\section{RESULTS AND DISCUSSION}

The static reservoir model is applied in the present study by using Rock Works software. It is usually referred to as the geological model (often abbreviated "geomodel"), and is a digital 
numerical model describing the initial state of the reservoir before any production of hydrocarbons has taken place, i.e. representing the spatial distribution of rock types with different reservoir properties. The petrophysical calculations can be performed for an entire reservoir or individually for any layers or fault segments that have been defined during model construction (Bjørlykke, 2015). The petrophysical heterogeneity of the reservoir units within the Mishrif Formation is due to variations in porosity, water saturation and fluid volume (Mahdi and Aqrawi, 2017). 2D models of facies and petrophysical properties are constructed for the Mishrif Formation in Majnoon Oilfield. It reflects the distribution of facies and petrophysical properties of the Mishrif Formation.

\section{Microfacies Analysis}

Four facies associations were distinguished, each of which represents a distinct depositional environment and includes several microfacies, and these are (1) Shallow open marine, (2) Shoal, (3) Back-Shoal, (4) Restricted marine.

\section{Shallow Open Marine}

Shallow open marine facies are common in Mishrif Formation in Majnoon Oilfield. The facies association includes mud-and grain-supported microfacies such as Foraminiferabioclastic wackestone-packstone (P1.1-A), Bioclastic wackestone (Pl.1-B), and Echinoderm packstone (P1.1-C). The shallow open marine environment is thought to have extended from shoal and reef areas into the very low energy environments of the outer shelf (Taghavi et al., 2006).

The primary components of these microfacies are bioclasts that have different sizes such as echinoderm (P1.2-B), and rudist (P1.1-C). Other important components include planktonic foraminifera. The secondary skeletal grains in this facies association include benthic foraminifera, algae, sponge spicules, and shell fragments.

\section{Shoal}

The shoal facies association is most important in the Mishrif Formation due to their high reservoir quality related to the dominance of the grain-supported microfacies that are affected by dissolution (Mahdi et al., 2013). This facies association consists of Bioclasticforaminiferal packstone-grainstone (Pl.1-D), Bioclastic grainstone (Pl.1-E), and Rudist grainstone (P1.1-F). The microfacies are rich in bioclasts, in addition to cemented grains that have micritic envelopes (P1.1-E).

The observed shoal microfacies in this study are equivalent to MFT-10, MFT-11, MFT12, and MFT-13 recognized by Mahdi et al., (2013) that reflect a high energy shoal environment. 


\section{Back-Shoal}

The back-shoal facies association is represented by Foraminiferal- bioclastic wackestonepackstone and Peloidal-foraminiferal packstone. The microfacies are rich in bioclasts (rudist, echinoderm), benthic foraminifera, peloids, in addition to gastropod (P1.2-G). Back-Shoal facies are interpreted to have been deposited in shallow water, low energy settings in a photic environment.

\section{Restricted Marine}

The restricted marine facies association is characterized by mud-supported facies. It includes Benthic foraminiferal wackestone and Bioclastic-foraminiferal wackestone-packstone (P1.1H). The main constituents are large and small benthic foraminifera (Miliolid, Nezzazata, Praealveolina), bioclasts, peloids, in addition to algae and Ostracoda.

The depositional condition is characterized by low energy as indicated by the mudsupported texture associated with the dominance of benthic foraminifera. A similar interpretation is recorded by Sherwani $(1983,1998)$ and Mahdi et al., (2013).

\section{Facies Associations Model}

A facies model captures the reservoir variability based on the sedimentological analysis of the core and wireline data, combined into a conceptual model of the reservoir depositional environment (Cannon, 2018). The 2D facies associations model of Mishrif Formation is built along two directions. The first pass through wells $\mathrm{Mj}-1, \mathrm{Mj}-10, \mathrm{Mj}-20$ and $\mathrm{Mj}-15$, and the second passes through $\mathrm{Mj}-11, \mathrm{Mj}-29, \mathrm{Mj}-10$ and $\mathrm{Mj}-3$ (Fig. 4).

Restricted marine facies occur in the uppermost part of Mishrif Formation at most wells $\mathrm{Mj}-10, \mathrm{Mj}-20$ and $\mathrm{Mj}-15$ except $\mathrm{Mj}-1$ well where the uppermost part consists of shallow open marine facies (Fig. 5). The high thickness of shoal environment occurs in the Mj-20 well middle part. While the lower part is predominantly consisting of the shallow open marine environment with thin intervals of shoal facies (Fig. 5). The uppermost part of Mishrif Formation at second section B-B' consists of restricted environment except Mj-29 well it where it starts with back-shoal facies. The high thickness of shoal facies occurs at Mj-11, Mj10 and Mj-3 wells (Fig. 6). In Mj-29 well shoal facies association also occurs at the upper part of the Mishrif Formation but as discrete intervals and interbedded with back-shoal and restricted facies (Fig. 6). Shallow open marine facies exist at the lower part of (Mj-11, Mj-29, $\mathrm{Mj}-10$ and $\mathrm{Mj}-3)$ wells. 


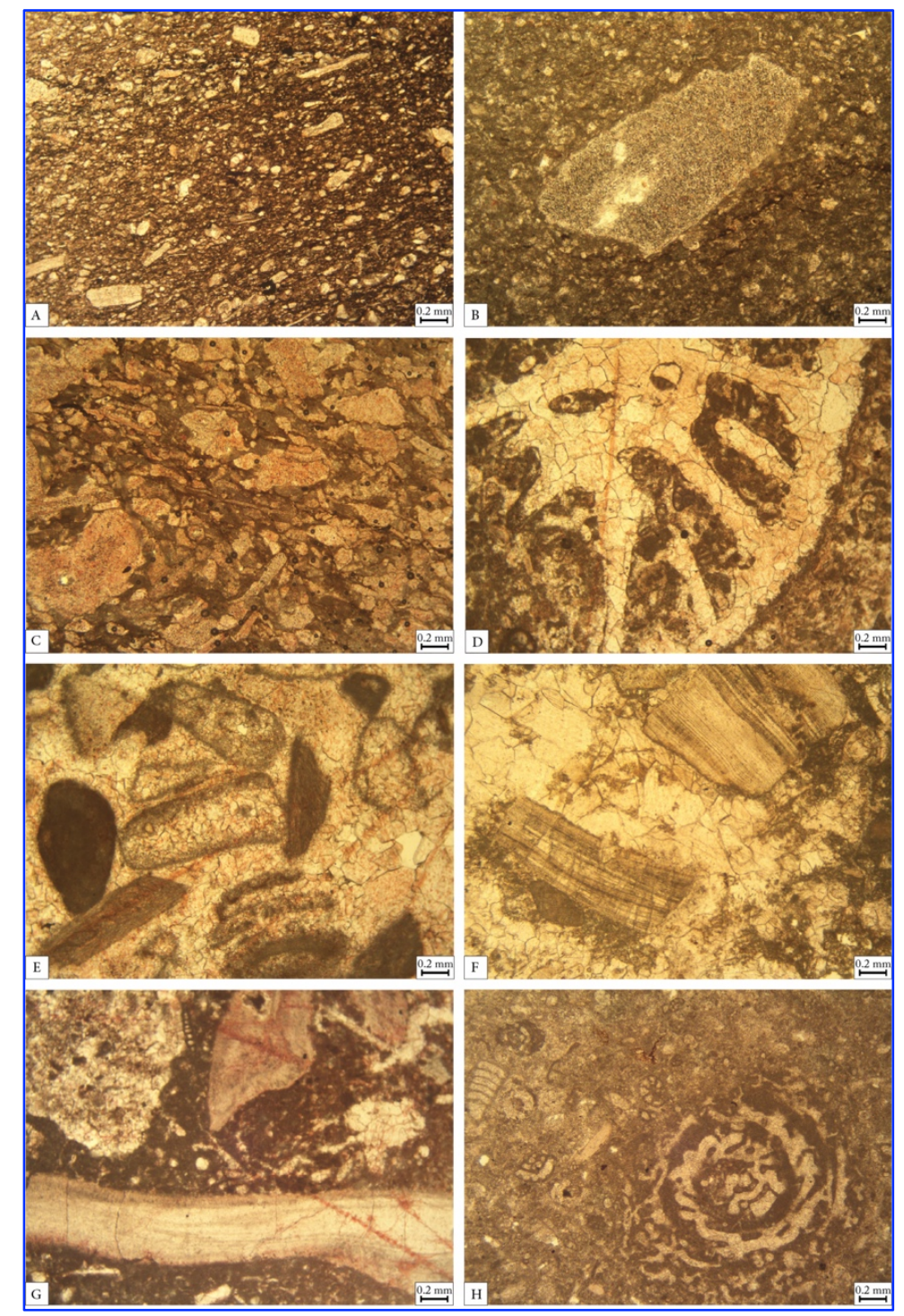

Plate 1: Microfacies, A. Foraminiferal-bioclastic wackestone-packstone, Shallow open marine facies associations (Mj-29, 2490m). B. Bioclastic wackestone showing echinoderm fragment, Shallow open marine facies associations (Mj-29, 2497.5m). C. Bioclastic packstone with compacted echinoderm bioclasts, Shallow open marine facies associations (Mj-29, 2534.25m). D. Bioclastic-foraminiferal packstone-grainstone, Shoal facies associations (Mj-29, 2536m). E. Rudist bioclasts and micritic envelops embadded in calcite cement matrix. Bioclastic grainstone, Shoal facies associations $(\mathrm{Mj}-29$, 2520.5m). F. Rudist bioclasts, Rudistid grainstone, Shoal facies associations (Mj-29, 2570m). G. Rudist and Gastropod shell fragment in Foraminiferal-bioclastic wackestone-packstone, Back-shoal facies associations (Mj-29, 2560m). H. Large benthic foraminifera and bioclasts. Bioclastic-foraminiferal wackestone-packstone, Restricted marine facies associations $(\mathrm{Mj}-1,2450)$. 


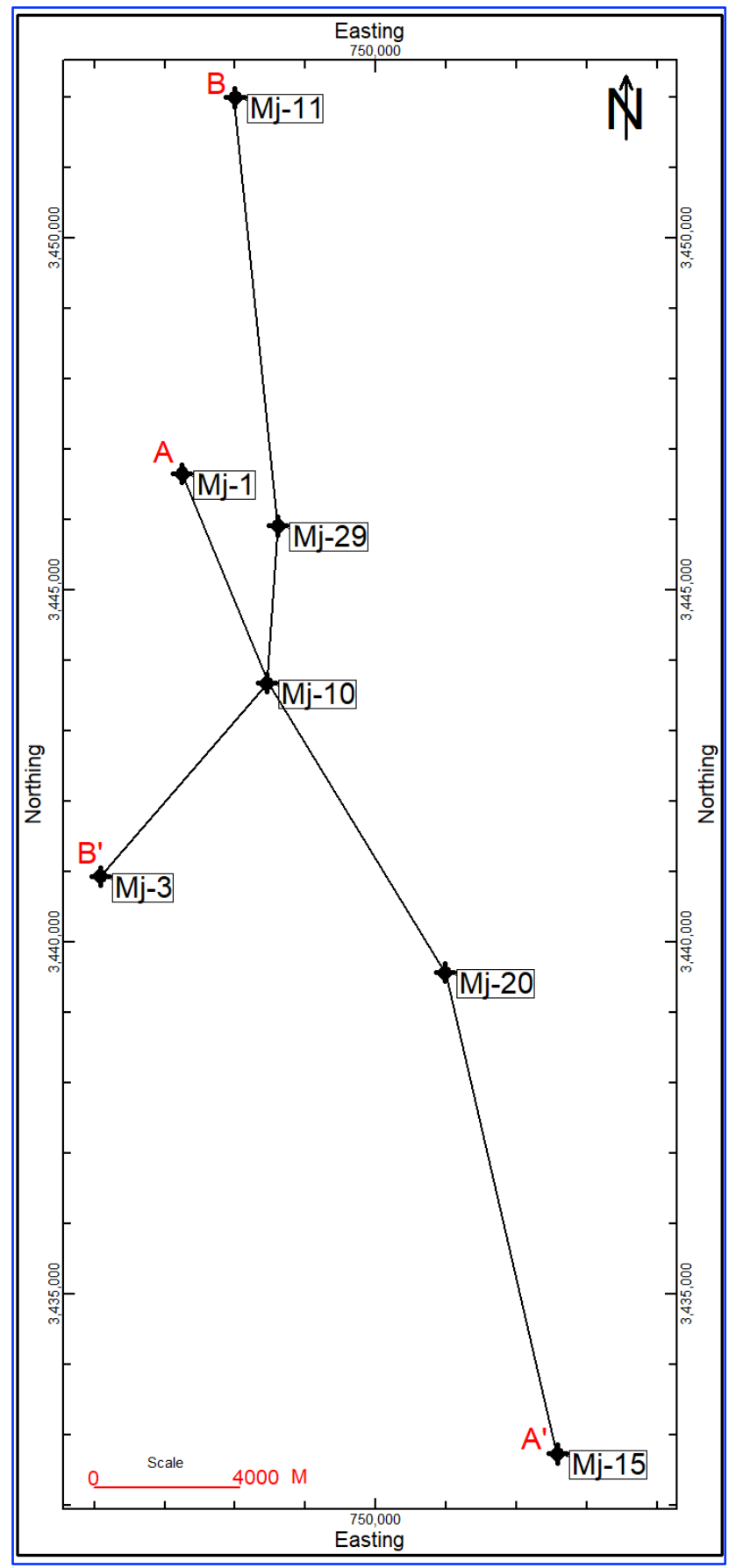

Fig.4: Location map shows the section's directions along where modeling study is done

\section{Petrophysical Model}

The petrophysical models include several important characteristics such as porosity $(\phi)$ and permeability $(k)$, formation bulk density $(\rho b)$ or sonic p-wave velocity (vp), the volume fraction of shale (Vshale) or fracture density (Fd) (Ringrose and Bentley, 2015). In this study, the focus will be the petrophysical model that includes effective porosity and water saturation. 


\section{Porosity Model}

The 2D models of effective porosity are shown in figures $(5 \&$ (6). Due to the high thickness of shoal facies in well $\mathrm{Mj}-20$, the highest effective porosity values are distributed around this well (Fig. 5). The effective porosity values between wells $\mathrm{Mj}-1$ and $\mathrm{Mj}-10$ are nearly similar, where the values increase towards the upper and lower parts of Mishrif Formation. The second section B-B' (Fig. 6) shows the distribution of maximum effective porosity values along $\mathrm{Mj}-11$ well in the uppermost part of Mishrif Formation. While the porosity increased at the upper and middle part of the Mishrif reservoir at wells $\mathrm{Mj}-29, \mathrm{Mj}-10$ and $\mathrm{Mj}-3$ (Fig. 6). The increment of effective porosity at different intervals of these wells is related to the presence of shoal facies (P1. 2-A, B).

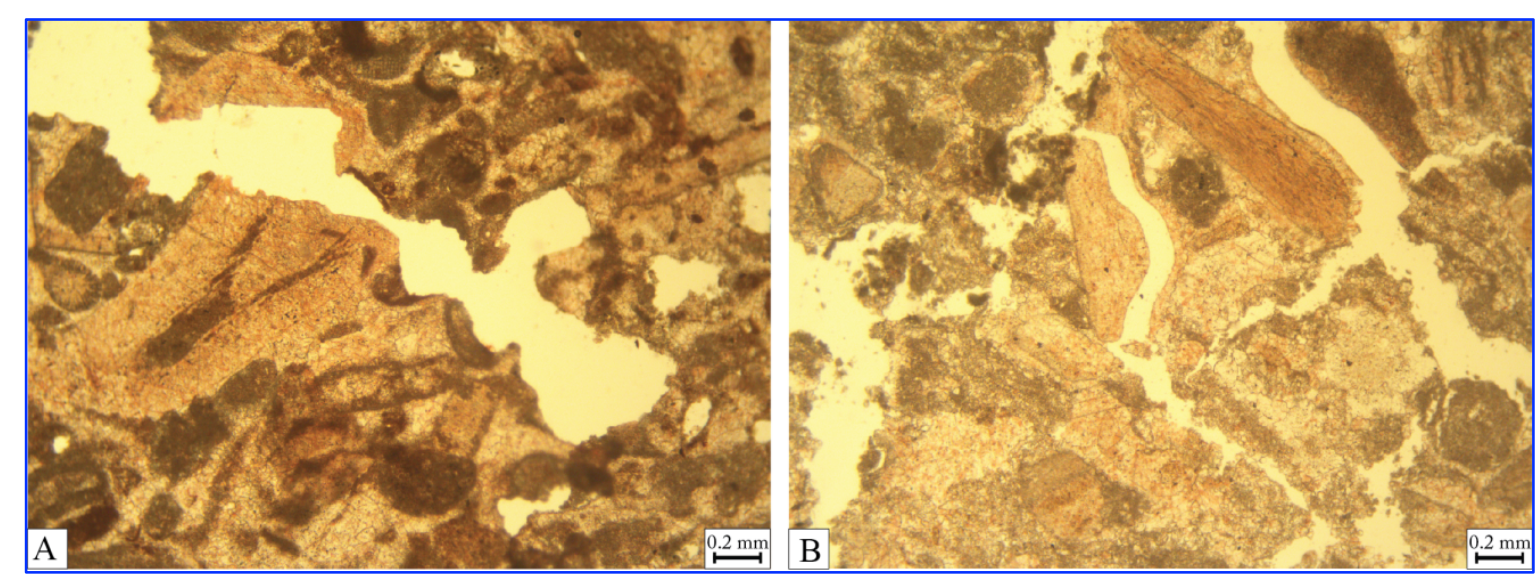

Plate 2: Pore types, (A) Cavern pores cut rudist bioclasts, shoal (Mj-29, 2536.15 m)

(B) Solution enlarged fractures in rudistid facies, shoal $(\mathrm{Mj}-29,2517.79 \mathrm{~m})$

\section{Water Saturation Model}

The 2D water saturation models at two sections show increasing values of water saturation at structurally lower parts of Majnoon Oilfield, which are characterized by shallow open marine and resticted facies associations. The highest water saturation at the lowermost part of well $\mathrm{Mj}-15$ is attributed to the existence of restricted marine facies and shallow open marine facies repectively.Therefore, maximum values of hydrocarbon saturation is predicted to occur towards crest parts of the structure of studied field as shown in wells $\mathrm{Mj}-1, \mathrm{Mj}-10, \mathrm{Mj}-20$ (Figs. 5, 6) which, is characterized by shoal facies. 


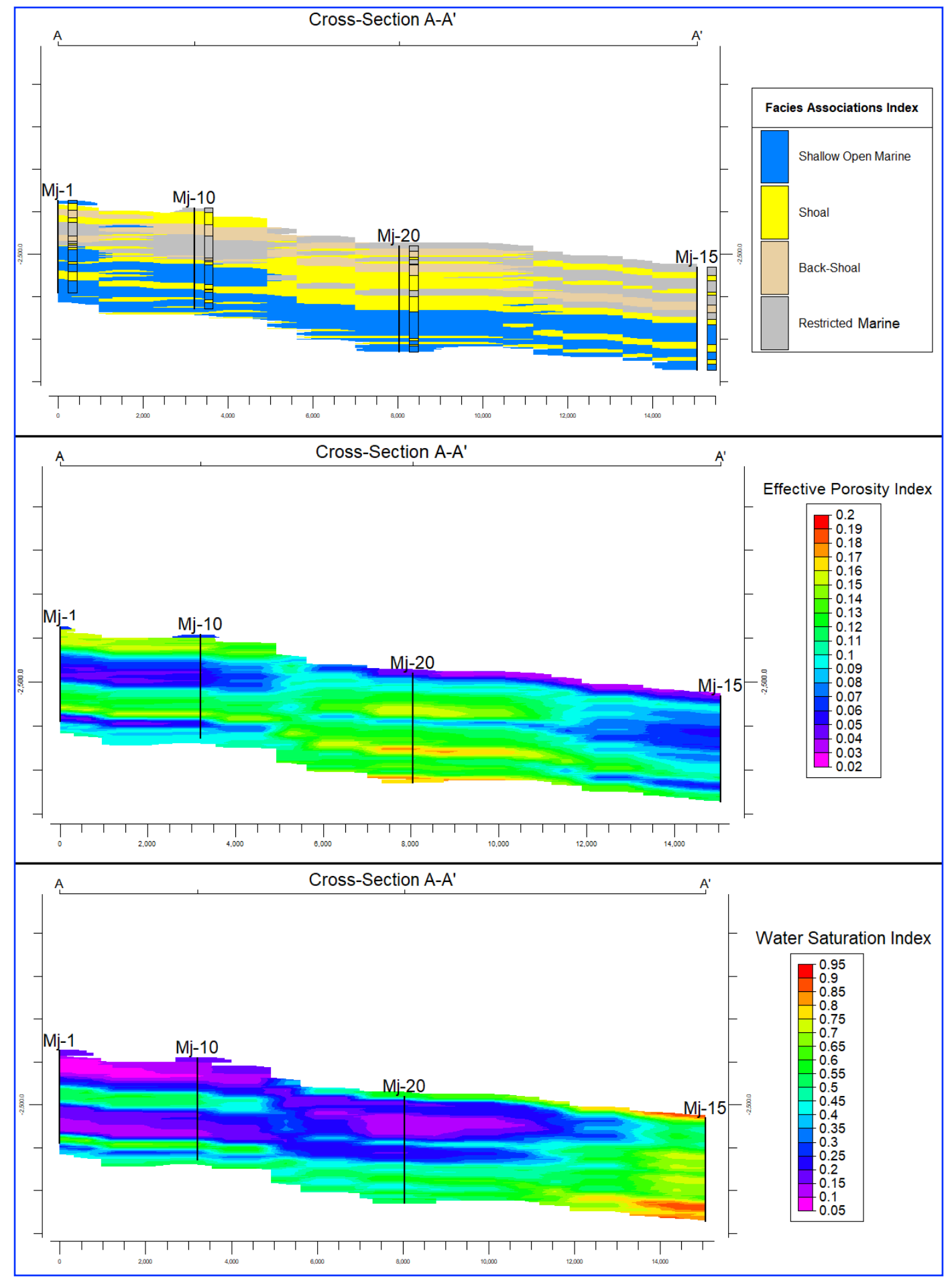

Fig. 5: 2D models of facies associations, effective porosity and water saturation for Mishrif Formation along cross sections A-A' in Majnoon Oilfield 


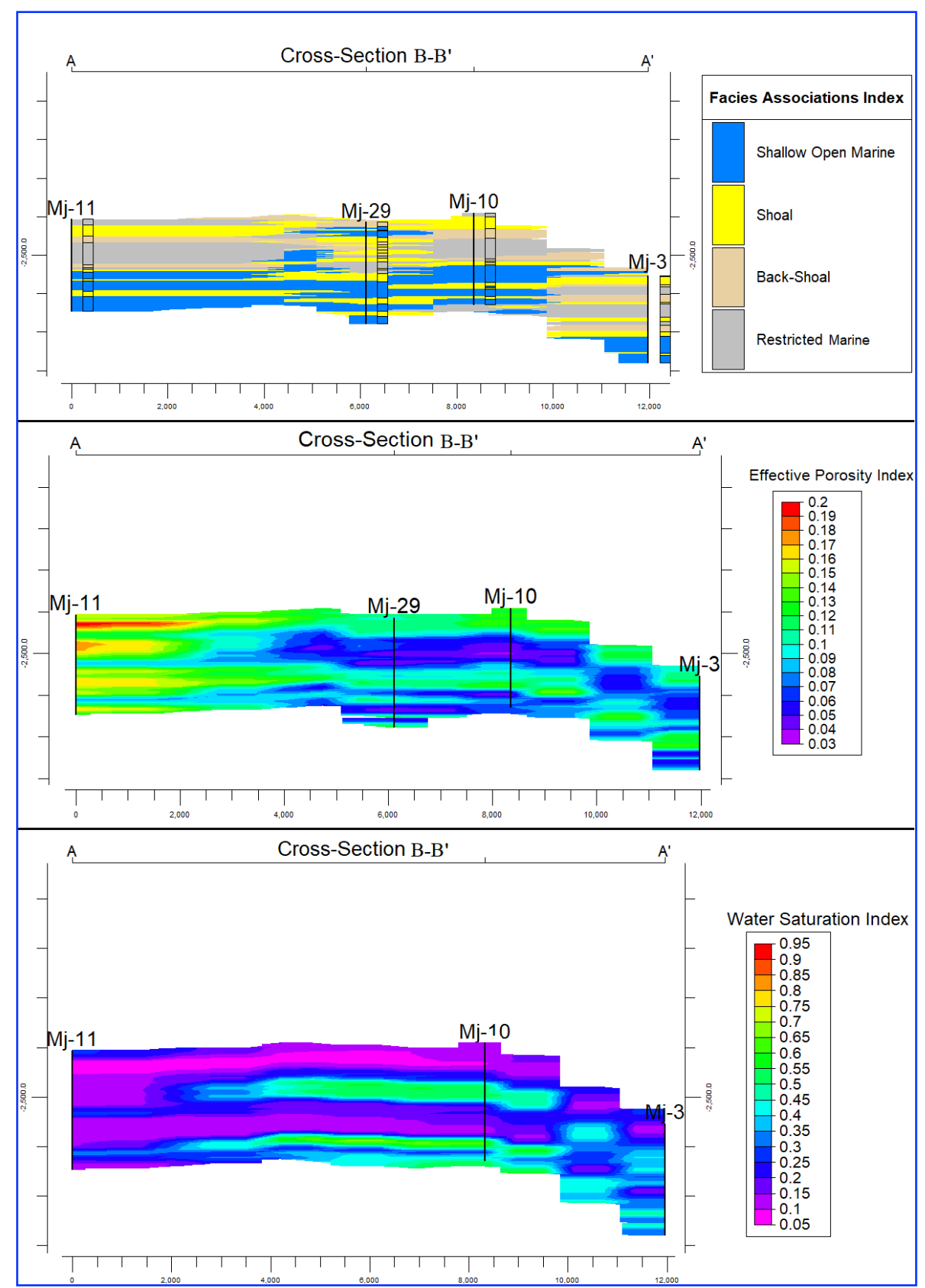

Fig. 6: 2D models of facies associations, effective porosity and water saturation for Mishrif Formation along cross sections B-B' in Majnoon Oilfield

\section{CONCLUSIONS}

In this study, the aim was the construction of 2D reservoir model of the Mishrif Formation to explain the distribution of facies and petrophysical properties (effective porosity and water saturation) by using RockWorks (2016) software. The 2D models have shown that the high thickness of shoal environment occurs in the Mj-20 well middle part. Due to the high thickness of shoal facies in well $\mathrm{Mj}-20$, the highest effective porosity values are distributed around the well. 
The distribution of maximum effective porosity values along Mj-11 well in the uppermost part of Mishrif Formation. Increasing the effective porosity is accompanied by the presence of shoal facies.

The 2D water saturation models at two sections show increasing values of water saturation at structurally lower parts of Majnoon Oilfield, which are characterized by shallow open marine and resticted facies associations.

The highest water saturation at the uppermost and lowermost parts of well $\mathrm{Mj}-15$ is attributed to the existence of restricted marine facies and shallow open marine facies, respectively. Maximum values of hydrocarbon saturation are predicted to occur towards the crestal parts of the field.

\section{REFERENCES}

Al-Ameri, T.K., Jafar, M.S.A., and Pitman, J., 2012.1D PetroMod software modeling of the Basrah Oilfields, southern Iraq. Arab J Geosci.

Aqrawi, A.A.M., Goff, J.C., Horbury, A.D., and Sadooni, F.N., 2010. The Petroleum Geology of Iraq, Scientific Press, Beaconsfield, UK, 424 pp.

Aqrawi, A.A.M., Thehni, G.A., Sherwani, G.H., and Kreem, B.M.A., 1998. Mid-Cretaceous rudist-bearing carbonates of the Mishrif Formation: An important reservoir sequence in the Mesopotamian Basin, Iraq. Journal of Petroleum Geology, 21(1): 57-82.

Archie, G.E., 1942. The Electrical Resistivity Log as an Aid in Determining some Reservoir Characteristics; AIME, $54 \mathrm{pp}$.

Bjorlykke, K., 2015. Petroleum Geoscience from Sedimentary Environments to Rock Physics, Second Edition, Springer Heidelberg New York Dordrecht London, $262 \mathrm{pp}$.

Braspetro, 1978. Final geological report on the well Mj-2-IRQ, 47 pp.

Buday, T., 1980. The Regional Geology of Iraq, Stratigraphy and Paleogeography, Dar Al-Kutub Publication House, Mosul, Iraq, $351 \mathrm{pp}$.

Cannon, S., 2018. Reservoir Modelling: A Practical Guide. Wiley Blackwell, 312 pp.

Jassim, S.Z., and Goff, J. C., 2006. Geology of Iraq. Dolin, Prague and Moravian Museum, Brno, Czech Republic, 1st Edition, 341pp.

Mahdi, T.A. and Aqrawi, A.A.M., 2017. Role of facies diversity and cyclicity on the reservoir quality of the mid-Cretaceous Mishrif Formation in the southern Mesopotamian Basin, Iraq. Published by The Geological Society of London.

Mahdi, T.A., Aqrawi, A.A.M., Horbury, A., and Sherwani, G.H., 2013. Sedimentological characterization of the mid-Cretaceous Mishrif reservoir in southern Mesopotamian Basin, GeoArabia, 18(1): 139-174.

Rabanit, P.M.V., 1952. Rock units of Basrah area, British petroleum company, (Unpublished Report).

Ringrose, P., and Bentley, M., 2015. Reservoir Model Design. A Practitioner's Guide, Springer Dordrecht Heidelberg New York London, 249 pp.

Sherwani, G.H., 1983. Depositional Environment and Stratigraphic Relationships of Mishrif Formation and Equivalents in selected boreholes, Southern and Middle Iraq. M.Sc. Thesis, University of Baghdad, 119 pp. (in Arabic).

Sherwani, G.H., 1998. Sequence Stratigraphic and Depositional Systems of Cenomanian-Early Turonian Formations in Southern Iraq. Unpublished Ph.D Thesis, University of Baghdad, 149 pp.

Taghavi, A.A., Mork, A., and Emadi, M.A., 2006. Sequence stratigraphically controlled diagenesis governs reservoir quality in the carbonate Dehluran Field, southwest Iran. Petroleum Geoscience, 12, 115-126.

VanBellen, R.C., Dunnington, H.V., Wetzel, R., and Morton, D.M., 1959-2005. Lexique Stratigraphique International.03 10 Asie, (Iraq), 333 pages. Reprinted by permission of CNRS by Gulf Petro Link, Bahrain. 